\title{
The Decline of Private Higher Education
}

\author{
Daniel C. Levy \\ University at Albany, 11 Maple Av, Delmar, NY 12054, USA. \\ E-mail: dlevy@albany.edu
}

No topic in private higher education study has attracted as great attention globally as has growth. This is appropriate as private growth has soared to nearly a third of the world's total higher education enrolment. But while private growth continues to be the dominant trend, important declines in private shares have emerged. These must be analysed and understood. What is private decline depends partly on definition. For the most part declines occur in private enrolment shares, rarely in absolute numbers. Declines also sometimes occur in private subsectors rather than in the private sector overall. Some declines are merely transitory. Short of actual decline, the slowing of private growth rates is also notable. After citing historical examples, we focus on contemporary social and political causes of private decline. The social causes are mainly two: diminution of social distinctiveness or groups that have fuelled private growth; demographic changes that fall hard on private sectors. The political causes analysed are three: government policy, ranging from hostile regimes to regulation; hefty expansion of the public sector of higher education; competitive partial privatization within public higher education. None of these dynamics reverses the continued dominant tendency of private growth but they do provide counter-tendencies important to grasp and with potential to accelerate.

Higher Education Policy (2013) 26, 25-42. doi:10.1057/hep.2012.26;

published online 6 November 2012

Keywords: decline; global; private higher education

\section{Introduction and Context}

Growth is as arresting as any theme about private higher education (PHE). Growth is the centre of public discussion, policy concerns, and scholarship about PHE. And for very good reason, as PHE growth has been spectacular (Kinser et al., 2010; Levy, 2010). The best estimate is that PHE now holds $31.3 \%$ of global enrolment (http://www.albany.edu/dept/eaps/prophe/). No region has been exempt from the growth. Very few countries have no PHE, whereas absence was common a couple of decades ago. Moreover, growth sometimes huge growth - continues mostly unabated. It is not like a powerful tendency has now peaked. Nor is any imminent global PHE peak predicted.

So why the provocation of the Decline of PHE? Because it is an untold reality; it has received only rare and passing mention with little analysis. And 
because growth is not a uniform, omnipresent, inevitable course. ${ }^{1}$ We find that declines of one sort or another occur even amid growth, that declines can be in certain types of PHE, or for certain time periods. Furthermore, it becomes clear that declines can occur in private shares of higher education even while private numbers grow - just as public higher education in recent decades has lost market share while growing in absolute enrolment.

Dominant trends often appear to be natural, so natural that they might seem permanent. But the huge expansion of the broad welfare state once appeared that way, yet was followed in the last decades of the 20th century by significant privatization. The same holds for the shares of public higher education and private higher education. Where we will be beyond the near future may seem clear but is not.

On the other hand, crying wolf also has a private education history. Eyecatching examples of decline have been taken as general trends or harbingers for private education overall. In the United States, this has happened with Catholic schools and colleges both. In higher education, Cassandras have bemoaned the decline, even extreme danger, for private colleges overall when in fact only some (usually small) were in trouble - and while new forms were emerging. . In reality, the US higher education private enrolment share has been remarkably stable for many decades at between one-fifth and one-fourth, just recently rising to $28 \%$ (Kinser et al., 2010). For various reasons we should be wary of extrapolating particulars of private decline into generalities about broad private decline.

This article identifies and tries to explain incidences of PHE decline. Most countries have not experienced private decline but, to explore decline, we focus on cases that show at least a period of decline. Thus, the countries discussed here are not typical but may prove typical of countries with PHE decline.

After sketching the historical context, the article focuses on (a) social factors and (b) political factors. In so doing we seek to establish categories (for the analysis of decline), taking us beyond single-country case studies. Such a global cross-national sweep or 'essay' is not a substitute for statistical or other intensive analysis in a national case study. But a principal hope is that this article will stimulate and guide those studies. ${ }^{2}$ Additionally, the piece is analytical, not normative: it does not treat declining PHE as either good or bad or the necessary object for corrective or promotional action by public policy.

Much of the reason to study and understand decline is the same as reason to study growth. The division of public and private sectors is an abiding concern of political economy (Kamerman and Kahn, 1989). It is a central question in social areas like education, at all levels. Public sector growth and then privatization have both been key topics in policy and social science scholarship. We want to know the size of private and public sectors and also their shape, as they may rise in some respects and shrink in others. ${ }^{3}$ Furthermore, in higher 
education, despite important instances of inter-sectoral overlap or blurring, the literature predominantly affirms strong private-public distinction (Levy, 2006a). Thus, the relative size of each sector is a significant question. In assessing it, we count private and public by their juridical designation, which generally overlaps ownership; if an institution is legally public we count it (and its enrolment) as public, regardless of its degree of 'privateness' in finance or administration. Private institutions are usually legally non-profit but increasingly they are legally for-profit as well.

\section{Historical Context: The Fall and Rise of PHE}

Private and public, in many policy fields, did not historically carry the same meanings as they usually do today (Starr, 1989). Specifically in higher education, government and religious or other private interests often worked together (Whitehead, 1973; Levy, 1986); the notion of a sharp private-public division or legal distinction was not dominant. With the rise of the nation state, however, the public side became ascendant, both in higher education and more generally. For Europe and Latin America this private decline occurred largely in the 19th century and continued into the 20th century. Higher education institutions saw more and more emergence of identifiable public and private tendencies - and the triumph was on the public side. The Church presence was often pushed out of the main universities, leaving a second-best option as the defensive creation of private religious universities (Levy, 1986). Various forms of private precursors sometimes remained, such as correspondence or missionary schools in Africa, but their share of higher education (a category on which they sometimes teetered precariously) declined markedly.

A second great global wave of public proportional ascendance can be linked to the 20th century growth of the welfare state in developed countries, with echoes in developing ones. In higher education and beyond the public proportional rise was mostly about its own growth (rather than a fall in private absolute enrolment). The chief global tendency for decades would be expansion of the state role in finance and rule-making. In the 1960s the pace accelerated. ${ }^{4}$ Along with shifts to the public side among existing institutions came the emergence and expansion of new public higher education institutions. India's private affiliated colleges and Chile's private universities were extreme cases in which institutions became much more public than private.

But these periods of historic private fall were followed by a reversal in recent decades. PHE growth has been part of a broad privatization. In much of the developed world the main public-private impact in higher education came in added privateness within existing institutions. The PHE sectoral explosion has been overwhelmingly in developing countries, traceable by regions (Levy, 2008). ${ }^{5}$ 
Latin America now has $49 \%$ of its enrolment in the private sector. Asia's figure is $36 \%$, though with by far the largest PHE raw numbers (Levy, 2010). All other regions have PHE averages under the global average of $31 \%$ but all have seen dynamic change. Central and Eastern Europe jumped from nearly 0\% PHE under Communism to even over $30 \%$ in a few countries. Since most of Western Europe has only marginal PHE, Europe overall is 16\% PHE. SubSaharan Africa is still lower but PHE proliferation has been striking since the 1990s. The Middle East has suddenly seen widespread creation of PHE since 2000. Commonwealth countries of mostly European-descent populations join Western Europe as outliers, reflecting the comparative rarity of PHE in developed countries, but important PHE advances are seen (Wells et al., 2007).

Even stability in PHE shares represents remarkable PHE growth in absolute numbers alongside the huge growth of public enrolments. That PHE's share of total enrolment has so often grown is of course more striking. The PHE surge has occurred in a variety of institutional types (Levy, 2008). They include religious, ethnic, and gender institutions and also ones that are 'semi-elite' (as world class elite PHE is almost non-existent outside the United States). But weightiest in sheer numbers have been demand-absorbing institutions. Key for them has been the yawning gap between soaring demand and existing supply, with governments unable or unwilling to finance massive growth in the public sector. These quite non-elite institutions are sometimes serious, with value added, yet sometimes they are dubious in worth. Some are legally non-profit (whether they behave that way or not) and some are legally for-profit. These demand-absorbing forms are prevalent throughout the developing world. Taken together they have been numerically dominant in most Asian countries from their PHE outset; whereas this dominance came relatively later in Latin America, it has been manifest there for decades. Particularly the dubious demand-absorbers that grow in an 'easy market' of high demand may later prove vulnerable to decline.

\section{Social Causes}

Two salient social developments have contributed to PHE decline. One is a waning of distinctive social realities that had given rise to PHE. The other is demographic decline.

\section{The waning of the distinctive}

Religious institutions may decline when their core social constituency declines. The Catholic education decline noted above has been a significant example. On one end, the Catholic share of total population has sometimes diminished. 
More importantly, deep affiliation with the religion, or at least the institutional manifestations of it, has declined. There is less religious privateness of the nominally Catholic institutions but the point relevant to the PHE share of enrolment is that there may be less reason to attend these institutions; although they have often been adept at attracting clients for other than religious reasons, the primordial affiliation becomes less of a magnet. For several inter-related reasons the phenomenon of decline in religious rationales for PHE is strongest in Latin America. ${ }^{6}$

Women's colleges provide another example of the decline of identity institutions. After mainstream higher education institutions opened themselves to women, there was of course diminished rationale for separate, private, women's colleges. Mission distortion also occurs as men are admitted to the women's college student body and occupy teaching and administrative positions as well. ${ }^{7}$ The heightened Japanese university access for women has undermined the tight association between women's and junior colleges, which are overwhelmingly private; also, as job hiring has become less the reserve of male university graduates, Japanese women have an increased incentive to go to universities rather than junior colleges.

\section{Demographics}

A different kind of socially based decline has little to do with distinctiveness. It is demographically induced. Obviously, the impact of a fallen or stagnant birth rate hits higher education only many years after it starts. ${ }^{8}$ Although demographic decline can affect both public and private sectors, we trace the logic of its notable impact on PHE; crucial is that outside the Americas the public sector is almost always preferred over the private (for reasons of cost, quality, and status). Declining demographics may produce a decline in the share of PHE overall as the most vulnerable PHE type is the largest type: demandabsorbing.

A related reality is that PHE has often risen rapidly, sometimes suddenly. In important respects it has done so in 'easy' circumstances, with the huge excess of demand over supply in higher education. Much PHE has not had to offer very much, other than access and the prospect or hope of a degree. This helps explain why the demand-absorbing subsector is most vulnerable when demand slows. In contrast, other private types offer more to customers than just a place in the system and thus are less vulnerable to demographically induced decline. It is the demand-absorbing subsector that is generally the least desired by students.

In addition, to the extent that demographic stagnation strains all higher education, or at least all but the leaders, even institutions other than private demand-absorbing ones need to adjust. Where public institutions ease selection 
requirements, to maintain enrolment levels, they may take in an increased percentage of the demand for higher education - leaving less for demandabsorbing PHE. Just as this PHE was such a beneficiary of soaring higher education demand, so it can get hit hard by slowing demand. Because vulnerability is greatest in the demand-absorbing subsector and this is easily the largest subsector, the potential for PHE decline is notable.

To be sure, the demographically induced PHE fall has been rare in the developing world. There the demand for higher education continues to grow rapidly, though not in every country. So precisely where the demand-absorbing subsectors are proportionally largest (i.e., in the developing world), PHE decline is least evident. But two important caveats: One is that non-elite PHE exists also in developed countries. ${ }^{9}$ Second is that demographics are becoming problematic even in some developing countries. For example, Thailand's number of secondary school graduates is falling and China has begun to see a decline in the population aged 15-19.

Overall, demographic decline has not affected Western Europe PHE much simply because PHE is small in most countries. But Portugal has been the Western European country with easily the largest PHE share - and it suffered a PHE decline from 36 to $25 \%, 1996$ to 2006. Some programmes have had no applicants and there are predictions of PHE institutional deaths or at least mergers (Teixeira and Amaral, 2008). ${ }^{10}$ Mergers in times of demographic stagnation relate also to the fact that many PHE institutions are very small, much more often than are public counterparts. Whether or not mergers bring enrolment decline, they obviously bring a decline in the PHE share of institutions.

Russia could become the most important case of PHE decline in Eastern Europe. Between 1990 and 2001 higher education almost doubled in size, and continued to grow until 2008. The great public growth obviously affected the share the rapidly growing private sector could attain, though PHE slightly increased (to $17 \%$ on the university side and $14 \%$ overall). But soon the number of secondary school graduates will be less than the entry quota for the public sector alone. Russians refer to the 'demographic pit'. ${ }^{11}$

Japan is a leading country case of demographically induced vulnerability and PHE decline. Japan is nearly unique in having both the stagnant demographics often associated with developed countries and the substantial PHE share (77\%) more associated with developing countries. 'Nearly unique' because South Korea is similar in both respects, with $78 \%$ of enrolment in PHE. ${ }^{12}$ In both countries PHE institutions have not been able to fill their government sanctioned quotas. ${ }^{13}$

With a declining birth rate since the mid-1970s and declining secondary school graduates since the mid-1990s, along with a recession hurting graduate employment, Japan may soon have only one applicant per higher education opening. Within PHE, decline has been acute among non-university institutions, 
often small ones, paralleling the Portuguese and US declines. ${ }^{14}$ More than 9 in 10 of Japan's junior colleges are private and these fell from 503 to 386, with a stunning enrolment plunge of more than half, from 1998 to 2008. Many PHE institutions seemed vulnerable and the government issued guidelines for closings.

Yet Japan is also a significant case of how decline may be curbed. Most dire predictions have not been born out. The PHE share of enrolment has remained steady at $77 \%$. The private share for university education is likewise stable private decline paralleled by public decline. The number of private universities has grown, though partly from elevating junior colleges to university status. Although private institutions have suffered enrolment decline among junior colleges, they have maintained their share and even their enrolment plunge has moderated very recently. For all the logic and hypotheses of demographically induced higher education decline falling disproportionately on PHE, this has not been the Japanese reality.

Why? Perhaps observers focused too much on shaky, small (private) institutions, over-estimated the magnitude of overall enrolment decline, and underplayed how demographic decline affects the public sector. Moreover, in Japan private status trails public less in teaching than in research, so private enrolment is not as vulnerable as in Europe. Finally, analysts often marginalize the role of policy change. Government has cut regulation while curbing public municipal and junior colleges, new private (and public) programmes attract working and adult students and foreign students, and the cohort rate has risen (to about $80 \%$ ). Nonetheless, Japan remains our biggest example of PHE decline in absolute enrolment.

\section{Political Causes}

What happens in the public sector - by government action or from within public higher education - can have major effects on the size of the private sector. Often, the effect has been positive, as when government restricts public size. Here, however, we focus on how government and public higher education policy can thwart PHE, sometimes bringing decline.

\section{Government policy}

Our analysis of government policy turns first to the macro level of regime type and then to the more micro level of regulation.

\section{Regime types}

The largest precedent for rising government and dramatic termination of PHE obviously lies in Communism, with the Soviet Union, its empire, and then 
China and other countries. South Vietnam's 11 private institutions were nationalized once the Communists came to power (1975). Other individual country examples of nationalization have included Pakistan under Ali Bhutto in 1972 and Turkey for most of the 1970s. Whether nationalizations are a thing of the past remains to be seen. But clearly government neutrality or favourability to private proportional growth cannot be assumed.

Short of nationalizing extremes, governments can become less favourable to PHE during particular administrations and under left-of-centre parties. New Zealand's Labor Party froze public subsidies for PHE in 2002. Market-oriented China highlights that in distinctly non-democratic national settings, with weak rule of law, PHE depends precariously on changing views of government or party leaders, sometimes varying at provincial and local levels. State variability has been salient in India and both the UGC (University Grants Commission) and the Supreme Court have made some decisions sharply detrimental to PHE at the national level. Whereas the Ethiopian government had lauded the rise of a private sector to a nearly $20 \%$ share, and sought collaboration with the World Bank for further expansion, in 2010 it suddenly issued sharp antiprivate policies. One was that each higher education institution must have $70 \%$ of its enrolment in science and engineering; though this is unrealistic for the public sector as well, punishment for non-compliance could hit the private sector much harder. A tandem astonishing blow was that PHE would be banned from three major areas: law, pedagogy, and distance education.

Latin America offers several cases of left-of-centre regimes bringing problems for PHE. Castro's Cuba is the extreme in abolishing PHE. Peru's populist military regime of 1968 took a hard line against PHE. Sometimes, official policy is not directly hostile to PHE but has negative consequences for it. Thus, Argentina's 1983 re-democratization brought sudden open admissions at the national public university, and the PHE share dropped from 22 to $13 \%$ by 1985 , to a low of 11 in 1987; a similar dynamic had occurred in a $17-12 \%$ decline in the early 1970s (Rabossi, 2010). By keeping public university tuition at or near zero, the Argentine and many progressive counterpart regimes have made the relative cost of $\mathrm{PHE}$ higher.

The Latin American neo-liberal rise of recent decades may have seemed to mark a decisive turn away from huge public expansion. But electorates have rebelled in many countries. Where leftist parties have won presidencies, as in Brazil, Chile (since replaced by a rightist party), and Argentina, the idea of direct threats to PHE is remote, though large public expansion is an option. In contrast, however, more leftist-populist regimes have gained power in Venezuela, Bolivia, Nicaragua, and Ecuador. They believe in expanded government and public sectors and often speak disparagingly of the private sector, including in higher education. We cannot yet assess impacts on PHE national shares in many countries. But Venezuela's Hugo Chavez, while for the most part not 
attacking PHE directly, for more than a decade spearheaded a mammoth expansion of the public sector, through creation and huge expansion of revolutionary institutions with open admissions policies beyond anything previously seen in the continent, so the explosion on the public side appears to have chopped the private share from $42 \%$ to about half of that.

\section{Regulation}

Short of regime change, regulatory restrictions have often been significant. Regulation that mostly pre-dated large PHE growth does not get much attention in this article, but other regulations come after. Restrictions may stem from public higher education lobbying or directly from government agencies. The desire to regulate heavily sometimes focuses on particular types of PHE, such as religious, foreign, or for-profit; the foreign and for-profit examples are largely contemporary. Important is pressure for stiff requirements on PHE, often patterned on what is the claimed norm in the public sector, as in accreditation agencies, or even for tougher requirements for the private sector than exist in the public sector. All this amounts to 'coercive isomorphism' (Levy, 2006a). If PHE meets the regulatory requirements, it may lose private distinctiveness but if it fails to meet requirements, it may lose market share.

PHE has often emerged explosively, without a central plan, and with only a paltry regulatory framework. This may be fertile soil for PHE growth acutely on the demand-absorbing side with institutions sometimes proliferating wildly. For a period government may appreciate the positive: expanded access is popular and it comes without strapped governments having to finance it. But then realities of low quality and fraud bring great concern. A lack of legitimacy affects not only the institutions but also government itself (for not protecting the public). 'Delayed regulation' ensues (Levy, 2006b). Licensing standards emerge or become much tougher, accreditation is introduced, and laws are promulgated.

Where proliferation was especially irresponsible, delayed regulation can lead to many closings or institutional mergers, as in Romania and El Salvador. Romania's private share enrolment fall - 36 to $22 \%, 1992$ to 2005 - came largely from regulation (Pachuashvili, 2009). In Argentina the 1995 creation of a national accreditation agency led not to closing existing PHE institutions but to much more difficult approval for new ones. Argentina now stands out in Latin America for lacking a large demand-absorbing private subsector. After establishing 22 new private universities, 1980-1995, Argentina established only seven from 1995 to 2008; more severe policy had existed from 1971 to 1989 , when there had been a ban on new private universities (Rabossi, 2010).

The importance of delayed regulation is underscored by its global reach. Delayed regulation has been noteworthy in Africa, Asia, Eastern Europe, and 
Latin America. ${ }^{15}$ In recent years regulations have sometimes been aimed particularly at for-profit PHE, a strong prospect in post-Mubarak Egypt. At the US national level, the recent huge growth of for-profits - dependent heavily on public student assistance - now provokes congressional concern to regulate recruitment and monitor subsequent employment.

Whether 'delayed' or not, regulation in matters like programme offerings sometimes exceeds that faced by public universities, with their relative autonomy, own statutes, venerable legitimacy, and political power. Examples include Argentina, Brazil, Japan, and Thailand. Even regulations identical to those in the public sector can undermine PHE if they are more challenging for PHE. In Russia, new regulations that compel PHE to use the same admissions criteria as the public sector is a danger for much of PHE. Accreditation, growing rapidly around the world, is a threat for what may be seen as both valid and invalid reasons, and again a particular threat to the demandabsorbing subsector.

Although accreditation and other regulations carry considerable risk for PHE size, they can also help secure part of PHE by bolstering its legitimacy. In contrast, subsidization is a public policy that may generally favour PHE size. But direct annual subsidization continues to be rare and carries risk of government rules such as ceilings on tuition. ${ }^{16}$ A public policy of low public tuition obviously works against private size.

\section{Public higher education: expansion}

Here we shift our focus from government policy to public higher education policy. But these are not fully separate; government typically is a major funder and influencer of what public higher education does. Nevertheless, there is usually some separation as governments do not try or are too weak to dictate all the public higher education policy they would like. Imposing (or raising) tuition is a common example. We explore how expansionary policies in public higher education — steered by government or not — can lead to PHE proportional decline.

The huge post-war development of US two-year public community colleges helped lower the country's PHE share from roughly one-half to roughly onefourth. In many countries of the former Soviet Union, the rapid private share rise stalled in the mid-1990s amid great public growth; Russia has been a dramatic case. Even where a private share continues to grow, it can of course be partly offset by large public growth, as with China today as well as some of Africa. The Mexican PHE share has held only steady at about one-third in most of the 2000s even while private enrolment has grown from 620,897 to 767,255 (http://www.sep.gob.mx/wb/sep1/sep1_Estadisticas). 
The Philippines' PHE fall from 81 to $65 \%$ between 1999 and 2006, after once being the world leader at $92 \%$ (Geiger, 1986), was a result of policy changes within public higher education. Government promoted the expansion of what could be called demand-absorbing publics, including at the local level, where governments kept tuition low. The Philippines generally had significant public tuition so this lower tuition contributed to public growth. In addition, there were also efforts at public expansion through visible steps to increase public quality and to offer scholarships for study in public universities.

The Colombian case displays a triple public expansion: establishment of new institutions, growth within existing institutions, and elevation of institutions to higher education status. The impact on PHE share would be visible. Colombia had been the first Spanish American country to follow Brazil to a majority PHE system, a status it held for decades. But recently PHE slipped to a minority of enrolment, without private absolute number declines (except by 3\%, 2002-2004). Between 1997 and 2007 PHE expanded 18\% while public higher education expanded 196\%. 'Room' for such huge public growth related to Colombia having lagged behind other large Latin American countries, with only $17 \%$ enrolment of the age cohort enrolled in higher education, 1997, before leaping to $32 \%$ by 2007 . Although private tuition had risen faster than inflation in this period and financial crisis had left scars, these were not the main reasons for the PHE proportional fall. The main reason was broad public policy to expand the public sector (Uribe, 2010). Indeed the expansion of lowcost non-university education is a global government tendency; it is a partial alternative to low-cost access via the private demand-absorbing sector. Additionally, the Colombian government incorporated part of SENA (National Training Service) — over 200,000 enrolments - to 'higher education' in technical and technological programmes. This too contributed to the PHE share slipping to $45 \%$, just where it had been in $1970 .{ }^{17}$

Like such technical programmes, normal schools have also been elevated to higher education. Thailand's PHE drop from 19\% in 1996 to today's $10 \%$ is due mainly to awarding university status to public teachers colleges, as well as to large growth in demand-absorbing public non-universities and in inexpensive fields of study in which privates have concentrated (Praphamontripong, 2010). ${ }^{18}$

\section{Public growth via internal privatization: the empire strikes back}

A special course of private decline (meriting its own section) comes, paradoxically, through privatization. Like other challenged public enterprises public higher education can partly privatize. Public universities almost never become private ones, a contrast to what has often been seen for banks, airlines, and other enterprises (Glade, 1986). ${ }^{19}$ But the growing privateness within 
public universities is an international phenomenon, though varying by region and country. Even the United States, with its long history of ample privateness in public institutions, now experiences further privatization.

One can refer to public university 'self-privatization' but in fact government figures in again. At one extreme the government might command or strongly urge the privatization. This has been the case with 'corporatization' in East Asia. The government purpose was not to compete with the private sector but that is an effect. ${ }^{20}$ Or government simply restricts its financial support of public higher education, often over the protest of public higher education; indirectly the university is forced to privatize financially.

Public sector partial privatization is sometimes but not always a response to the challenge posed by PHE gains. Either way, the public universities in question seek to improve their management such that they are more like their private counterparts. Management may become more hierarchical, seeking efficiency in coherent choice and administration of activities, and fund-raising may be undertaken (Clark, 1998). Activities often turn toward job-oriented fields, where PHE has been concentrated, sometimes fields that public universities had resisted. ${ }^{21}$ This is commercialization and is sometimes carried to the MS level, as in Romania (Nicolescu, 2007). Entrepreneurial partnerships with foreign universities may help buck up the public universities. ${ }^{22}$ Most public university privatization intensifies public-private competition and can partly combat areas of private strengths. Given the persisting natural advantages of low or no tuition and often of traditional status, a degree of such public university privatization can be an effective bump against PHE growth. Thus, partial privatization in public universities can make higher education overall more private while reducing the PHE share of total enrolment.

Sometimes this privatization and enrolment growth comes from creation of new units within existing public universities. These units are largely private in nature, clear challenges to the expanding private sectors. The public university empire strikes back. A dramatic feature of the 'module II' units is that their students pay, usually about what PHE students pay. Identified examples are mostly high-level public universities, though not necessarily the very top ones.

The dynamics for the new units are as follows. The public university decides how far its budget can carry it for free (or low tuition) students and admits accordingly. Stopping at that point, however, would allow private places a shot at desirable students who would fall short in their effort to gain access to the restrictive public quota. That is how semi-elite private universities have tried to become the 'first second choice' (Musial-Demurat, forthcoming) for good students who fail to make the elite public free quota. But now the public universities build a second quota, a second tier, a module II, and incorporate tuition-paying students. ${ }^{23}$ These units may well have financial and even management characteristics more like those in good private universities than 
like common practice within their own institution. A documented case is Kenya, where the PHE share fell from 19 to $13 \%$ by 2004 and each sector's efforts are challenges that lead to counter-efforts in the other sector (Otieno and Levy, 2007). The new public-private competition brings risky choices. ${ }^{24}$

Post-communist Russia has these module II programmes. As noted, Russian PHE has done well to hold its enrolment share; once again the private sector shows resiliency. This has much to do with private management and flexibility. ${ }^{25}$ But the public competition still has restrictive effects on PHE. Significant is the pressure on tuition. Even the high status privates may have to hold tuition below that in the public module II programmes. And lower tuition is all that demand-absorbing privates (the majority of the privates) are able to use to compete, and yet leaves them without the resources that might allow expansion.

With parallels in neighbouring Armenia, Georgia provides the most closely documented case of PHE proportional decline resulting from public university creation of fee-charging modules (Pachuashvili, 2007). With sudden and large PHE growth Georgia had thrust itself into the post-communist lead with Poland, Estonia, and Romania. But 34\% in 1996 became 22\% in 2006 and there was even a period of absolute PHE enrolment decline (Pachuashvili, 2008). Self-financed students constitute the leading revenue source for surging public university programmes in information technology, law, business administration, and foreign languages, joined by branch campuses. From $8 \%$ of the public enrolment in 1994 , self-financed students came to be $43 \%$ by 2002. As in Kenya, module II students came to outnumber PHE students.

The dates of steep PHE decline also point to the public sector privatization as the key cause of Georgia's PHE decline. Both the rapid increase and ensuing fall in the PHE share occurred amid a fairly unchanged regulatory regime and broader political-economic picture. Fundamental shifts in regulation did not come until the 'Rose Revolution' in 2003. Before then PHE enrolments had already dropped some $15 \%$ of market share. Similarly, the impact of a downward demographic trend was negligible as the country's population stagnation did not hit higher education until 2006.

Internal privatization proves to be a potent way in which the public empire strikes back. The module II programme is a salient manifestation, with admission into it of fee-paying students. An increase in public sector and even overall system privatization may be compatible with a shrinking PHE share of enrolment.

\section{To Here and From Here}

It is not all up, up, up when it comes to the private sector of higher education. There are several types of PHE decline and there are many reasons for PHE decline. ${ }^{26}$ History provides context and precedents. Most contemporary PHE 
declines can be analysed as basically sociological or political. The sociological is divisible into a slippage in demand for distinctive types of institutions and demographic dips. The political side includes the advent of regimes hostile to PHE, regulation, and major public expansion, including partial privatization within the public sector.

For analytical purposes we have treated separately our identified decline factors, often focusing on one cause in one country at a time. Indeed sudden falls do often stem overwhelmingly from one cause: regime change with the rise of Communism in China, open admissions in public higher education in Argentina, elevation of schools to the higher education level in Thailand, or the start of module II programmes in Kenya. But factors overlap as well. Russia shows three causes at work simultaneously: demographics, regulation, and privatized programmes within public universities.

Yet the very breadth of factors figuring into PHE decline can also be taken as underscoring the formidability of PHE growth. PHE grows significantly despite all the decline factors identified in this article. Sometimes dynamics that work against private growth operate simultaneously with dynamics that bolster such growth. Most of the factors involved in decline apply to a time and place, or a few times and places. Japan stands almost alone (outside countries that abolished PHE) in showing a sharp drop in PHE numbers and even Japan has not seen a decline in PHE market share. More common is country decline in PHE market share (not numbers) and even that applies only to a minority of countries and often the PHE numbers in those cases continue rising impressively. The most vulnerable PHE is the non-elite, demand-absorbing type but this underscores that other PHE types are not usually very vulnerable. In all instances in which PHE has been banned it has since re-emerged, except for Cuba and North Korea. Moreover, PHE institutions are not inevitably hapless sufferers; evidence of action includes reaching out to new kinds of students, in new modalities, including internationally. ${ }^{27}$

It turns out that PHE decline is multi-faceted and depends on definition. We should distinguish between 'raw' decline in absolute numbers and proportional decline, including where the decline is fundamentally a function of large-scale fresh public growth. Particular types of PHE are particularly vulnerable to certain dynamics, as seen with religious PHE and a decline in societal distinctiveness or with demand-absorbers and declining demographics or rapid expansion of low-status public higher education. A particular type of PHE may suffer decline while other PHE types do not. We even see situations in which the rising type is rather new and is one cause of the relative decline of an extant type. Notable today is the institutional establishment and growth of for-profit forms. Factors relevant to PHE growth or decline continually evolve.

In sum, even though growth remains the major trend for PHE, the decline of PHE warrants analysis for contemporary dynamics as well as historical and 
future ones. It is also warranted for how it puts mighty, recent, continuing, and anticipated PHE growth into perspective. The major and traditional question of how society divides its activities into private and public sectors is today overwhelmingly answered in higher education as a shift to the private, but it is neither a uniform nor unrelenting shift.

\section{Notes}

1 Whereas this article focuses on inter-institutional proliferation and decline, one might consider a parallel in differentiation and de-differentiation of programmes (Huisman, 2000).

2 This global conceptual guidance has already yielded dividends for Argentina (Rabossi, 2010), Colombia (Uribe, 2010), and Thailand (Praphamontripong, 2010). On the other hand, the few existing case studies already have informed our global essay.

3 This is not to imply a simple zero-sum game. As many have shown for a range of social spheres (Salamon, 1995), the growth of government and the welfare state has often gone hand in hand with the growth of the private non-profit sector.

4 Instances of nationalization notwithstanding, what higher education usually witnessed was a marked shift to increased publicness of legally public universities that had been more mixed in publicness and privateness, as in England. This is the flip side to today's marked increase of privateness within legally public institutions.

5 The only developed countries with majority private enrolments are Japan, South Korea, and Taiwan.

6 Latin America is the clearest example of where Catholic universities represented the 'first wave' of private growth (Levy, 1986). Catholicism has been a weaker motivation since, though many students attend for non-religious reasons, as they do in Africa and Asia, where Protestant and Muslim institutions also gain enrolment.

7 Group distinctive colleges are more associated with private than public sectors but there are public women's colleges and public religious (Islamic) ones.

8 Materially similar to a domestic demographic decline is a decrease in the student population from overseas. Where PHE has targeted overseas students it can be particularly vulnerable to decline.

9 Another broad socio-economic challenge comes from economic crisis. The effect could be severe for PHE if fewer middle class families can afford private tuition. Again top tier institutions may feel less impact while demand-absorbing institutions suffer.

10 Neighbouring Spain also sees demographic decline but its PHE is less concentrated in demandabsorbing institutions. Portugal's PHE complains that government has failed to respond to lowered demand for higher education overall by restricting public sector openings, the same complaint made by PHE in Thailand (Praphamontripong, 2010).

11 Information on Russia from Suspitsin (forthcoming). In Poland, few institutions have closed and the high PHE share has held, but major decline is possible.

12 South Korea's PHE has similarly had problems filling freshman spots and non-elite PHE outside Seoul is especially vulnerable to decline or forced mergers (Yonezawa and Kim, 2008). Taiwan is a proximate example of demographic stagnation and a huge private sector, with consequent threats to demand-absorbing PHE.

13 In a less-developed setting, many Indonesian PHEIs also face enrolment problems (Moeliodihardjo, 2009). Although Latin America continues to be characterized mostly by PHE growth, Brazil shows candidate totals lagging openings.

14 By $200028 \%$ of even universities in Japan's private sector failed to meet their enrolment targets (Yonezawa and Mori, 2009). The universities (not just private) have taken to offering luxuries 
and tuition cuts (Fackler, 2007). Japanese PHE has suffered also from generous pension plans and risky derivative trading.

15 The impact on PHE shares is logical and in some cases empirically demonstrable but the degree of cause and effect cannot always be easily detected. Latvia, which was regionally aberrant for initially having ample regulation, has recently grown to have a high PHE share, $33 \%$ (Pachuashvili, 2008).

16 Although Japan's recent de-regulation may be benefiting a challenged PHE sector, the secular fall in its government subsidization of PHE hurts.

17 PHE recovers a bit from the establishment of government aid to students. Uribe (2010) refers to Colombia data from http://menwebmineducacion.gov.co/info_sector/estadisticas/superior/.

18 Such elevation to higher education status is a major aspect of academic drift. In Western Europe the demise of 'binary systems' rarely had a big effect on private-public shares since the education in question was mostly public.

19 Dutch research universities may now constitute an exception. Several US states have contemplated full privatization.

20 This increased public-private competition through partial privatization of public institutions is intensified when joined to demographic decline, as in South Korea (Chon-Hong, 2002).

21 For example, Uruguay, Latin America's last South American country to allow PHE, has recently seen intensified private-public competition as the public university has partly privatized and inter-sectoral competition is typically strong in graduate fields where the private sector is active (Landoni, 2007).

22 Partnerships with domestic private colleges, on the other hand, may buck up both the public universities and the private colleges and not contribute to any aggregate PHE decline.

23 So establishing tuition-based programmes can help public universities gain market share whereas a general increase in tuition at public universities can lead to loss of public market share, as it decreases the 'tuition gap' between public and private institutions.

24 Thus, for example, competition pushes Kenya's leading private universities to raise salaries and benefits, but such raises require tuition increases. On the other hand, Kenya also shows PHE resiliency through evening courses, new campuses, investments in staff development, and holding tuition just below that in public universities' fee-paying modules.

25 Russia's good private institutions stress curriculum that is current, practical, and job-relevant. PHE has also sometimes shown itself adept at fitting Bologna measures in bachelor and masters programmes.

26 Mostly outside the scope of this article is a different kind of private decline, a decline in privateness in private institutions. The strong and indeed more powerful counter-consideration, however, is the rising privateness in public institutions.

27 In Central and Eastern Europe and former Soviet republics, subject to demographic and public expansion pressures described at length in this article, only 5 of 22 countries saw any PHE decline, 2000-2004, whereas 17 saw an overall increase (Pachuashvili, 2009). Slantcheva (2010) finds mostly growth in the last decade in Eastern and Central Europe, with sharp or lasting decline both rare.

\section{References}

Balzer, H. (2011) 'Russian Higher Education to 2020', Russian Analytical Digest 97: 2-5.

Chon-Hong, K. (2002) 'Private Higher Education in Korea', in UNESCO PROAP (ed.) The Report of the Second Regional Seminar on Private Higher Education, Bangkok, Thailand: UNESCO PROAP.

Clark, B. (1998) Creating Entrepreneurial Universities: Organizational Pathways of Transformation, Oxford: International Association of Universities and Elsevier Science Ltd.

Fackler, M. (2007) 'As Japan ages, universities struggle', New York Times, 22 June.

Higher Education Policy 201326 
Geiger, R. (1986) Private Sectors in Higher Education: Structure, Function and Change in Eight Countries, Ann Arbor, MI: University of Michigan Press.

Glade, W. (ed.) (1986) State Shrinking: A Comparative Inquiry into Privatization, Austin, TX: Institute of Latin American Studies.

Huisman, J. (2000) 'Higher education institutions: as different as chalk and cheese', Higher Education Policy 13(1): 41-53.

Kamerman, S. and Kahn, A. (eds.) (1989) Privatization and the Welfare State, Princeton, NJ: Princeton University Press.

Kinser, K., Levy, D., Silas, J.C., Bernasconi, A., Slantcheva-Durst, S., Otieno, W., Lane, J.E., Praphamontripong, P., Zumeta, W. and LeSota, R. (2010) 'The global growth of private higher education', ASHE Higher Education Report, 36(3).

Landoni, P. (2007) 'Dinamicas public/privadas en el desarrollo de la educacion de posgrados: Comparando la experiencia de Argentina, Brasil, Chile y Uruguay', paper presented at the II SAECE conference, 14-16 June, Buenos Aires, Argentina (available on http://saece.org.ar/ papers2.php).

Levy, D. (1986) Higher Education and the State in Latin America: Private Challenges to Public Dominance, Chicago: University of Chicago Press.

Levy, D. (2006a) 'How Private Higher Education's Growth Challenges the New Institutionalism', in H.-D. Meyer and B. Rowan (eds.) The New Institutionalism in Education, Albany: State University of New York Press, pp. 143-161.

Levy, D. (2006b) 'The unanticipated explosion: private higher education's global surge', Comparative Education Review 50(2): 217-239.

Levy, D. (2008) 'The enlarged expanse of private higher education', Die Hochshcule 2: 19-35.

Levy, D. (2010) East Asian Private Higher Education: Tendencies and Policy Options, Washington, DC: World Bank.

Moeliodihardjo, B.Y. (2009) Equity and Access in Higher Education: The Case of Indonesia. Interim Report, Washington, DC: World Bank.

Musial-Demurat, J. (2012) 'Polish private higher education: inter- and intra sectoral differentiation', Dissertation, Department of Educational Administration and Policy Studies, University at Albany, Albany, NY.

Nicolescu, L. (2007) 'Institutional Efforts for Legislative Recognition and Market Acceptance: Romanian Private Higher Education', in S. Slantcheva and D. Levy (eds.) Private Higher Education in Post-Communist Europe, New York: Palgrave Macmillan, pp. 201-222.

Otieno, W. and Levy, D. (2007) 'Public disorder, private boons? Inter-sectoral dynamics illustrated by the Kenyan case', Program for Research on Private Higher Education. Working Paper 9, University at Albany, NY, http://www.albany.edu/dept/eaps/prophe/publication/paper.htmlWP9.

Pachuashvili, M. (2007) 'Changing patterns of private-public growth and decline: the case of Georgian higher education', Program for Research on Private Higher Education, Working Paper 10, University at Albany, NY, http://www.albany.edu/dept/eaps/prophe/publication/paper.htmlWP10.

Pachuashvili, M. (2008) 'Private-public dynamics in post-communist higher education', Die Hochschule 2: 84-93.

Pachuashvili, M. (2009) 'The politics of higher education: governmental policy choices and private higher education in post-communist countries', Doctoral Dissertation, Department of Political Science, Central European University.

Praphamontripong, P. (2010) 'Intra-sectoral diversity: a political economy of Thai private higher education', Unpublished Doctoral Dissertation, University at Albany, State University of New York, Albany.

Rabossi, M. (2010) 'Universities and fields of study in Argentina', Program for Research on Private Higher Education, Working Paper 15, University at Albany, NY, http://www.albany.edu/dept/ eaps/prophe/publication/paper.htmlWP15. 
if. Daniel C. Levy

T. The Decline of Private Higher Education

42

Salamon, L. (1995) Partners in Public Service: Government-Nonprofit Relations in the Modern Welfare State, Baltimore, MD: The Johns Hopkins University Press.

Slantcheva, S. (2010) 'Ups and downs across Central and Eastern Europe', International Higher Education (61): 13-14.

Starr, P. (1989) 'The meaning of privatization', in S.B. Kamerman and A.J. Kahn (eds.) Privatization and the Welfare State, Princeton, NJ: Princeton University Press.

Teixeira, P. and Amaral, A. (2008) 'Can private institutions learn from mistakes? Some reflections based on the Portuguese experience', Die Hochschule 2: 113-125.

Uribe, L. (2010) 'The decline of Colombian private higher education', International Higher Education 61: 12-13.

Wells, P.J., Sadlak, J. and Vlăsceanu, L. (2007) The Rising Role and Relevance of Private Higher Education in Europe, Bucharest, Romania: UNESCO-CEPES.

Whitehead, J.S. (1973) The Separation of College and State: Columbia, Dartmouth, Harvard, and Yale, 1776-1876, New Haven: Yale University Press.

Yonezawa, A. and Kim, T. (2008) 'The future of higher education in the context of a shrinking student population: policy challenges for Japan and Korea', in OECD Higher Education to 2030, Vol. 1, Demography, OECD Publishing.

Yonezawa, A. and Mori, R. (2009) 'Learning outcomes and quality assurance: challenge of Japanese Higher Education', paper presented at the 2009 International Conference on Quality Assurance and Student Learning Outcome of Higher Education in Asia-Pacific Region, Taipei, Taiwan, 15 June. 